\title{
Investigation of L2 Motivational Self System : A Comparative Study of Undergraduates from Displaced and Resettled Regions in Sri Lanka
}

\author{
K.S.N. Prasangani ${ }^{1 *}$ \\ ${ }^{1}$ Department of English Language Teaching (DELT), Faculty of Social Sciences \& Languages, \\ Sabaragamuwa University of Sri Lanka, Belihuloya \\ *nilushikap@yahoo.com
}

\begin{abstract}
This study investigates the motivation profile of the L2 undergraduates in the disadvantageous communities in Sri Lanka based on L2 Motivational Self System. Undergraduates from rural and war affected (resettled) areas were considered as disadvantageous learners due to the lack of human and physical resources for their learning. The large scale questionnaire study was conducted among 918 Sri Lankan public university science undergraduates. They were non-English major students who voluntarily participated for the questionnaire survey. The collected data were analysed by using the Structural Equation Modelling and models were developed to emphasise the key motivational factors. The results of the Structural Equation Modelling indicated the ideal L2 self as the strongest causative factor for learning English among rural and resettled undergraduates. The findings of the study reveal the strong ideal L2 self among the disadvantageous undergraduates in Sri Lanka. This study can be used for the theoretical and pedagogical implications, and future research in the similar Asian and South Asian contexts.
\end{abstract}

Key words: Displaced Learners, English Learning Motivation, Ideal L2 Self, Social Goals

\section{Introduction}

English learning motivation has been discussed in different contexts and raised the important consideration of the learner differences. Anyhow, English learner motivation based on the economical, regional and political issues seemed to be crtical in the current English as a Second Language (ESL) world [Elabbar, 2016, Kormos \& Kiddle, 2013, Lamb, 2012, You \& Dörnyei, 2016]. More importantly, the factor identification of Sri Lankan undergraduates motivation to be made by prioritising history, national policies, environmental displacement, urban and rural diviations and civil war experiences [Canagarajah, 2005, Davis, 2015, Liyanage, 2014].

The distribution of urban and rural population has greater implications for the methodologies of L2 motivation studies since there is a marked difference between learner ability yet when English is offered as a subject in universities, few students are motivated to perform well in the subject. Presently, there are studies in motivation within the qualitative tradition that seem to reveal far more about the concerns of the researcher and learner self than focusing on the learnability issue and then there are those within the quantitative tradition who often appear more concerned with statistical rigour and innovative procedures than the human stories behind their numerical data. This study provides a broader motivational perspective of the Sri Lankan science undergraduates by considering the regional differences and communal differences.

Recent studies have revealed that science postgraduate students' English proficiency is inadequate [Raheem et al., 2007]. Specially, due to Sri Lanka's structural dependency on the centres for research, for the communication of knowledge and advanced training from the developed countries [Altbach, 2005] English is highly valued. Presently, Sri Lankan science students have to heavily depend on the scientific publications of English speaking countries, because the world's leading scientific publications are dominated by them [Tardy, 2004]. Sri Lankan science undergraduates' lack of English competency is markedly seen through their inability to connect with the new scientific and technological innovations of the globalised world. One example is that Sri Lanka's medical professions failed to transfer new scientific technology during the tsunami relief operation in 2005 [Baldsing, 2013]. Thus science undergraduates as the future gatekeepers of transferring new scientific knowledge to the Sri Lankan community need to be equipped with sound scientific knowledge and communication skills that are largely built in English. For that, an investigation into the English learning motivation of the science students is compulsory. Presently, no large scale quantitative study on the factors that affect the L2 motivation of Sri Lankan science undergraduates has been conducted. Existing studies have focused on identifying the importance of English and employability of graduates [Hayes, 2010, Punchi, 2001, Raheem et al., 2007, Raheem \& Wijetunge, 2009, Ratwatte, 2012, Wedikkarage, 2009, Weerasekara, 2014] but they have not involved large scale population sampling such as this. Any study has hardly looked at urban and rural and war affected factors. Currently, Sri Lankan science undergraduates' English learning motivation cannot be simply identified through a common model due to the huge urban and rural disparity of the country. Sri Lankan undergraduates who are coming from rural and war affected areas have lacked 


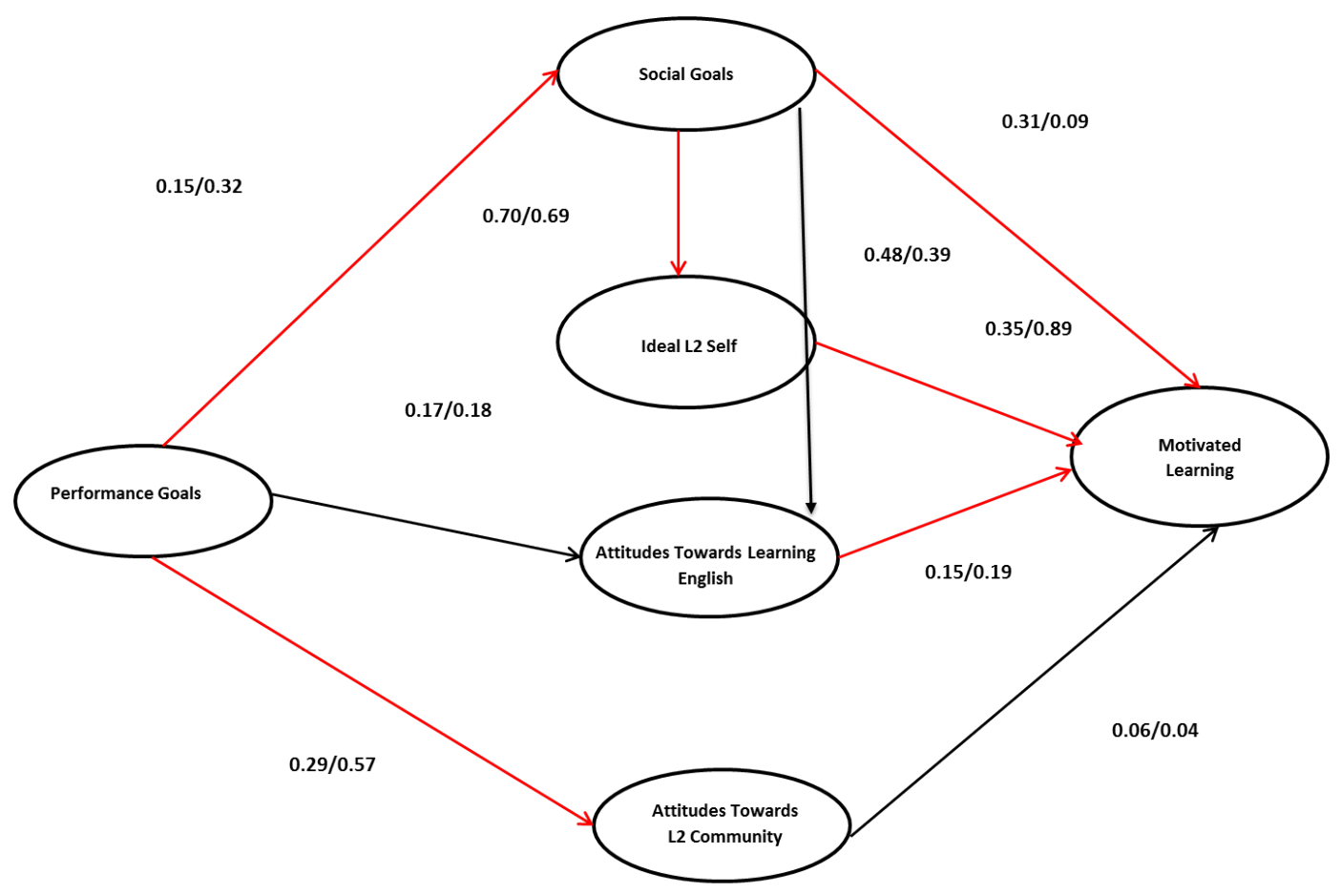

Figure 1: Urban versus rural learners' motivated learning behaviour

the opportunities to improve their English fluency due to the civil war, natural hazards and poverty. Further, the gulf between education policy and practice in Sri Lanka remains wide and mostly unbridged due to the lack of funds and political interference [Liyanage, 2014]. This situation has contributed to a lack of human and physical resources for rural schools and its population over time. Specially, $6.7 \%$ of rural learners attained the mastery of English compared to $21.6 \%$ of urban learners [UNICEF, 2013]. The failure of division of human and physical resources caused to marginalise and widen the gap between urban and rural [Davis, 2015, Liyanage, 2014]. According to the educational statistics, the rural and war affected schools belonged to the "uncongenial" or "very uncongenial" condition due to the lack of infrastructure and facilities [Ministry of Education, 2013]. Majorly, unequal distribution of teachers and lack of teachers make these learners more vulnerable [Davis, 2015, Liyanage, 2014]. Furthermore, the tsunami disaster (2005) and civil war (1983-2009) affected these rural learners' education severely. Their education was disturbed by the closure of schools, displacement of families, distance to the schools, lack of transport, shortage of teachers and educational facilities and poor living conditions in resettled locations [UNICEF, 2013]. In addition, the Structural Adjustment Policies implemented by the Sri Lankan government in 1977 limited the education expenditure to less than $2 \%$ of the Gross Domestic Product. This has also caused the declining of quality of education and increased the urban and rural disparities in the education [Liyanage, 2014]. Specially, the war affected learners' English learning was discouraged by the "Tamil only policy" for nearly three decades and they became more vulnerable due to the tsunami hazard in 2005. In fact, the disparity between urban and rural is wide in their English learning due to the lack facilities and teachers, although sufficient studies have not been conducted to address the real context of those issues. These have implications for their English in the university and academic performance when English happens to be the medium of instruction. There is also a need to gauge from the grassroots themselves the type of English that is being valued by Sri Lankan rural and war affected science undergraduates.

Researchers often found the impact of weak English competency to handicap the Sri Lankan science undergraduates in the academic performance and future career [Raheem et al., 2007, Raheem \& Wijetunge, 2009, Weerasekara, 2014]. Weerasekara et al. (2014) stated that students find problems in understanding lectures, practicals, demonstrations and communication at the university and this has strong implications for their final grading. Thus, English learning motivation is crucial to their academic performance in the university and the future professional career of the Sri Lankan science undergraduates. Given that English has become the Lingua Franca of sciences in the modern era [Tardy, 2004], effective communication skills in English remain compulsory for undergraduates in general and science undergraduates in particular. Presently, Sri Lankan science undergraduates are lacking communicative skills even in their mother tongue [Baldsing, 2013] and the situation is worse for English which is recognised as the second language but rarely spoken in some parts of the island. 
Table 1: Demographic profile of the participants

\begin{tabular}{llcc}
\hline \multicolumn{2}{c}{ Background details } & N & $\%$ \\
\hline Gender & Female & 508 & 55 \\
& Male & 410 & 45 \\
Year of study & & & \\
& 1st year \& 2nd year & 498 & 54 \\
& 3rd year \& 4th year & 420 & 46 \\
Academic discipline & Agriculture & 311 & 34 \\
& Applied Sciences & 326 & 36 \\
& Geomatics & 95 & 10 \\
& Science \& Technology & 186 & 20 \\
Residence & & & \\
& Urban & 538 & 59 \\
& Rural & 380 & 41 \\
& Non-war affected & 782 & 85 \\
Mother tongue & War affected & 136 & 15 \\
& Sinhala & 771 & 84 \\
& Tamil & 147 & 16 \\
\hline N=918 & & & \\
\hline
\end{tabular}

In fact, a host of factors affect the fresh Sri Lankan science undergraduates' ability to use the language at the university as well as in the work place. Given that motivation arises both individual and learning environment there is the need to investigate key factors that play a role in motivating science undergraduates at the university.

One of the bigger challenges in understanding learner motivation specific to a particular setting would be the need to relate the learner to the social context in which he/she exists. In this matter, the study of motivation has often focused on motivation as an individual goal [Kormos et al., 2011], communal or family goals [Csizér \& Kormos], performance goals and personal interest; where some learners were either motivated not due to the specific reasons and this often affected the learner's performance over time. In recent years, greater consideration has been given to the dynamic, social nature of motivation, looking at how motivation changes over time and in response to social context [Islam et al., 2013, Prasangani \& Nadarajan, 2015]. The primary aims of this study is to adopt a research framework that uses both the learners' psychological factors and social factors. It also seeks to respect previous research coming from a variety of perspectives in the social sciences. Many of the advances in L2 motivation theory have resulted from research concentrating on a single aspect of the motivation process but in this study the researcher wishes to contribute to building a model that considers the broader picture of language learning motivation, displaced learner motivation and war affected community's motivation. Presently, a number of factors such as Ideal L2 self [Dörnyei, 2009]; motivated learning [Taguchi et al., 2009]; ought to L2 self [Taguchi et al., 2009]; attitudes toward L2 learning [Papi, 2010]; attitudes toward L2 community [Islam et al., 2013] motivate learners to learn and master English. Here educators and society value motivation in learning for its own sake as well as for its long term 4 contributions. This includes integrative and instrumen6 tal motivation which have consequences for the individual learner's self-esteem, confidence, career and aca34 demic achievement. The literature on motivation may 36 be plenty spanning from preschool to private English 0 language education, but the bigger challenge is to un20 derstand how the learner motivation specific to a particular setting relate to the learner's social context in 9 which he/she exists. In this matter, this study focuses 1 on motivation as individual goals, regional goals and communal goals.

In covering the factors that motivate Sri Lankan undergraduates, decisions have had to be made about which areas to prioritise since history, national policies and environmental displacement have created differences between urban and rural population for decades and the learning environment is making it necessary to identify the similarities and differences between learner factors and learner ability [Canagarajah, 2005, Davis, 2015, Liyanage, 2014]. In making decisions about the rural and urban learner population every effort has been made to stay as close as possible to the Sri Lankan government's classification of the urban and rural based on the regional divisions [Department of Census and Statistics, 2011]. The distribution of urban and rural population has greater implications for the methodologies of L2 motivation studies since there is a marked difference between learner ability and yet when English is offered as a subject in universities, few students are motivated to perform well in the subject. At present, there are studies on the issues of learnability and statistical models than the true stories behind the data. This study provides a broader motivational perspective of the Sri Lankan science undergraduates by considering the regional differences and communal differences.

This study attempts to find empirical evidence for the rural and war affected (resettled) university students' motivated learning behaviour and factor effects. More specifically the following research questions will be addressed by the study.

1. What are the key motivational factors affect for the English learning motivation of the rural learners?

2. What are the key motivational factors affect for the English learning motivation of the displaced and resettle learners?

The primary objective of the study is to use the L2 Motivational Self System to investigate the relationships between the L2 learner's self and social factors that influence in English language learning. 
Gardner's (1985) pioneering socio-educational model has highlighted integrativeness as the key motivator of L2 motivation. However, Gardner's (1985) model has questioned lately due to the difficulty of explaining L2 motivation via integrativeness. Dörnyei (2009) reformulated Gardner's study and developed a new model to explain L2 motivation based on the learner self which was more meaningful for the globalised L2 learners. Dörnyei's (2009) L2 Motivational Self System has greater relevance for the Sri Lankan ESL context due to the changes happened after the globalisation.

Dörnyei conducted a large scale study of 13,000 Hungarian learners to find the L2 motivation of the global English learners. This study reformulated the integrativeness and instrumentality as "ideal L2 self" and "ought to L2 self". Dörnyei (2009) designed the L2 Motovational Self System including ideal L2 self, ought to L2 self and learning experiences as a result of the longitudinal Hungarian study.

\section{Methods}

Data were collected from a motivation questionnaire based on Dörnyei's L2 motivation self-system. The collected data of 918 students from two Sri Lankan public universities were analysed. Table 1 provides the demographic profile of the participants. The sample comprised of urban $(n=538)$ and rural $(n=380)$ undergraduates from various science programs. There were more female participants $(55 \%)$ compared to male participants (45\%). The present study used Strctural Eqaution Modelling as the major statistical method to create the models for Sri Lankan undergraduates based on the regional and communal differences.

\section{Results and Discussion}

The model in Figure 1 established the ideal L2 self to be the strongest causative factor for learning English in Sri Lanka. In accordance with the results, chi-square was significant at $\mathrm{p}<0.001$ due to sample size. The model fit measures of Goodness of Fit (GFI) 0.921, Root Mean Square Error of Approximation (RMSEA) 0.043, Standardized Root Mean Square Residual (SRMR) 0.075, Root Mean Square Residual (RMR) 0.078, Comparative Fit Index (CFI)0.919 and Adjusted Goodness of Fit (AGFI) 0.895 met the traditionally accepted measures. Further, the model has established a good fit with the norms x2 of 2.672. Interestingly, the model also indicated a significant difference between the urban and rural youths behaviour with rural youths displaying a very strong ideal L2 self compared to urban youths at 0.89 and 0.35 respectively to the motivated learning. In other words, there is a positive relationship between the ideal L2 self and motivated learning behaviour.

The second SEM model looked at war affected and non-war affected students' motivated learning behaviour (See Figure 2). In accordance with the results chi-square was significant at $\mathrm{p}<0.001$ due to sample size. The model fit measures of GFI (0.918), RMSEA (0.044), SRMR (0.090), RMR (0.085), CFI (0.911) and AGFI (0.891) met the traditionally accepted measures . Although SRMR value is higher than the accepted cut off value of 0.08 , its value is below 0.10 which does not indicate problems for the model [Hair et al., 2014]. Further, the model has established its good fit with the norms $\times$ 2 of 2.812 .

The data indicated significant differences between war affected versus non war affected youths. The ideal L2 self remained the strongest causative factor for learning English for all. The youths whose came from war affected regions demonstrated a stronger ideal L2 self compared to the non-war affected youths. Social goals remained an equally strong factor for war affected learners suggesting that social milieu had not affected learner's motivation for learning English.

The third SEM model relates factor effects for the motivated learning of rural Tamil and Sinhala (see Figure 3). The results of chi-square was significant at $\mathrm{p}<0.001$. The model fit measures of GFI (0.849), RMSEA (0.055), SRMR (0.091), RMR (0.090), CFI(0.876) and AGFI (0.813) met the traditionally accepted measures. In accordance with the results the ideal L2 self was seen as the strongest causative factor for learning English amongst both groups. However, the rural Tamil L2 learners relationship between ideal L2 self and motivated learning compared to the rural Sinhala L2 learners was much higher at 0.85 compared to the Sinhala speakers which was only 0.65 . In terms of social goals and the ideal L2 self, the Sinhala learners were greater than Tamil learners as 0.72 compared to 0.62 . However, the relationship between social goals and motivated learning for the Tamil learners suggest a negative correlation suggesting the Tamil learners and the rural population in general did not associate social goals with doing well in English as necessarily translate into gainful employment. The scars of the war may still be a bitter reminder for many of these young people. In terms of attitudes, the rural Tamil L2 learners indicated a stronger relationship between performance goals and attitudes towards learning English at 0.61 compared to Sinhala learners who only show a 0.16 correlation. In terms of performance goals and attitudes towards the L2 community, both rural communities seem to demonstrate a high coefficient at 0.66 and 0.55 . In terms of attitude towards the L2 community and motivated learning, the coefficient value was at 0.27 for the Tamils compared to 0.07 .

Taken together, all three groups continued to demonstrate the ideal L2 self to be the strongest causative factor for Sri Lankan undergraduates. Also, performance goals, social goals, ideal L2 self, attitudes towards learning English, attitudes towards the L2 community contributed to motivated learning.

Sri Lankan science undergraduates' ideal English speaking self showed significant difference due to the regional variation. Interestingly, the results indicated 


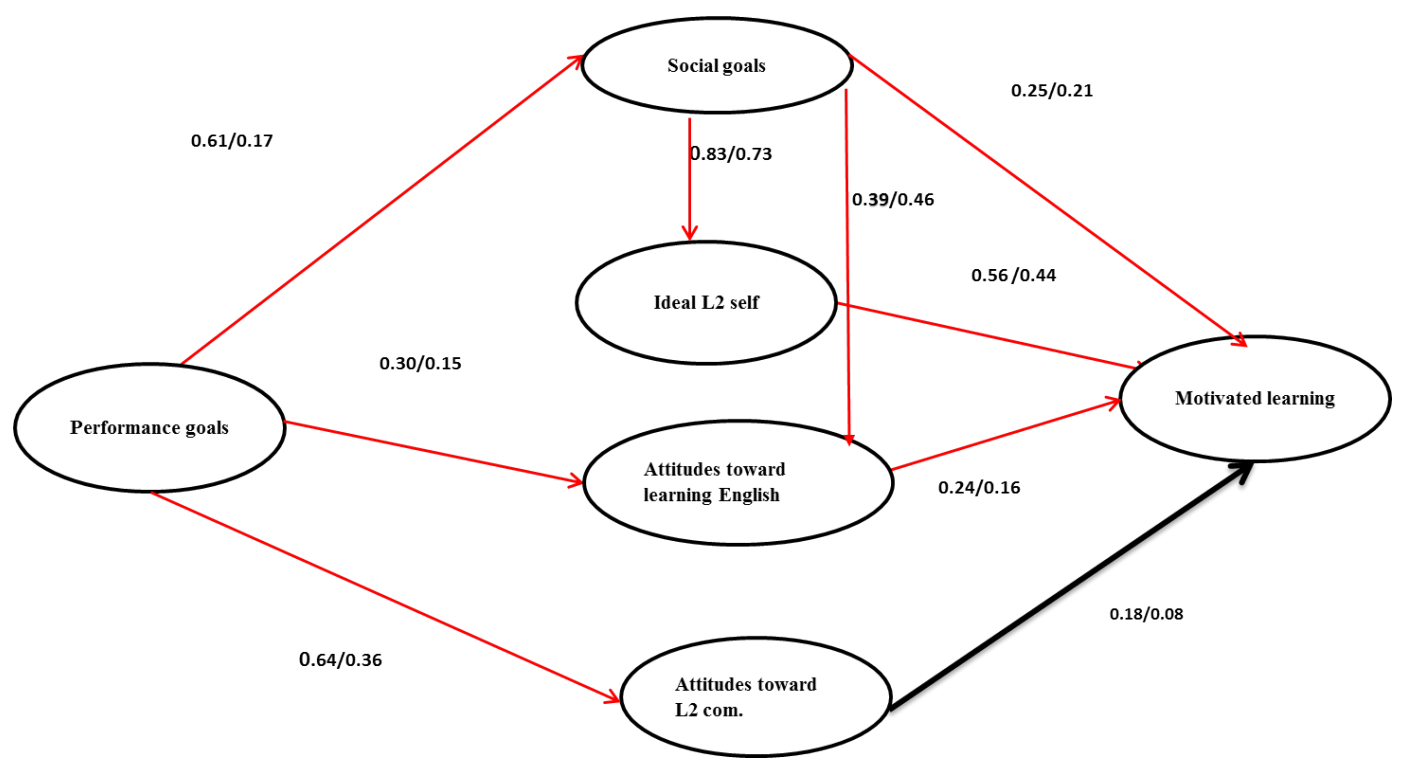

Figure 2: War affected versus non- war affected undergraduate's model

the strongest ideal L2 self among the rural science undergraduates $(\beta=0.89)$. This is in contrast with the other Asian motivation studies conducted in Indonesia [Lamb, 2012] and China [You \& Dörnyei, 2016] where they found a strong ideal L2 self among the urban learners and weak ideal L2 self among the rural learners due to the limited resources and exposure. This might be because in Indonesia and China English is a foreign language, but in Sri Lanka English is a second language and also it is a Link Language for the inter-ethnic communication. Further, English learning has a significant historical setting in Sri Lanka compared to the settings of Indonesia and China. Added to that the selection of the science undergraduates may cause to have a different result in Sri Lankan context.

In Sri Lankan context rural learners seem to be different from the other Indonesian and Chinese English learners due to the historical learning experiences they gained from the British colonial period (1796) onwards. From the British period onwards the linguistic capital of English happened to be a limited resource for the rural learners and it was a "prestigious language" of urban elites. Further, the rural community had been disconnected from the social, economic and cultural capital of the country due to the lack of English fluency [Bailey, 1998]. Further, they were "marked" as inferior among the urban elites [Fernando, 1977]. This continuous demarcation and marginalisation led rural learners to form strong ideal L2 self, or need of communicating in English because they have realised that English competency is the only way up for the social mobility of Sri Lanka since English happened to be the linguistic capital of the country.

Additionally, the recent ethnic violence they have experienced during their schooling have created some necessary conditions to motivate their English learning due to the various guises of capital attached to English and English is the only way to move up in the society. However, for Sri Lankans English happens to be the only way up and out. Further, it cannot be denied that the reason that the majority of rural Tamil and Sinhalese asylum seekers choose English speaking Australia and Canada as their destinations is because of this valuation of cultural capital. This would also be a fine reason to have a strong ideal L2 self.

In addition, the globalisation and information technology revolution had changed rural learners' anti-English attitude of considering English as a weapon or "kaduwa" (sword) of oppression [Kandiah, 1984], because English became the global language [Dörnyei \& Ushioda, 2011] and language of their own to express their feelings among the community members rather than a "colonial baggage" [Bernaisch, 2012].

Further, the expansion of the usage of mobile phones and social media (especially Facebook) among the young generation in Sri Lanka also caused the strong ideal L2 self. In fact, they have realised English is the only key to connect with the global community and information technology.

Added to that, the compulsory English medium instruction in higher education also brought about their strong ideal L2 self, because in Sri Lanka science students have to follow the compulsory English medium. In fact, to retrieve advanced and new scientific information English happens to be the only way. Additionally, science students' desire to go overseas for postgraduate studies and work also remarkably influences for their ideal L2 self, because they lack ample science postgraduate opportunities in Sri Lanka.

Moreover, rural learners realised the inadequacy 
of the vernacular languages to survive in the local and international contexts due to English functions as the economic and symbolic capital of the country [Canagarajah, 2005]. From the British colonial period onwards English happened to be the symbolic and economic capital of the country, eventhough the nationalistic movements occurred against the dominance of English and protect the national languages. English proficiency enables people to gain lucrative positions in the country after the independence [Rajandran, 2009, Senaratne, 2009]. Furthermore, the introduction of the "liberal economic policy" (1977) and "link language" policy in 1987 further confirmed the symbolic importance of English in the country to gain economic success and social success, because government sector jobs are limited and English dominated private sector started to dominate the economy of the country. Thus English happened to be the economic and symbolic capital of the country and rural learners cannot deny its importance.

Added to that the strong English speaking self or ideal L2 self of the rural science undergraduates implies their English learning goal. Specially, they lack the supporting family background and supporting school learning environment to improve their English. In fact, they expect to accomplish their English learning goal in the university and the failure of achieving the goal may handicap their future opportunities and country's development. Thus, finding is critical for the pedagogical practice of the country, because this uncovers the context specific local knowledge [Canagarajah, 2009] of the Sri Lankan rural English learners' need. This knowledge is vital in motivating the English learning further by "knowledge partnering" [Eversole, 2015] rather than importing foreign models. In fact, pedagogical practice should be framed to protect and maintain the ideal L2 self of the rural learners to achieve their expected learning goals.

Furthermore, Sri Lankan science undergraduates' English learning needs are different due to the war torn and non-war torn of the country. In general, for both groups the ideal L2 self appears to be the strongest causative factor for their English learning motivation, but notably war affected and rural Tamil science undergraduates have stronger ideal L2 self compared to the non-war affected science undergraduates. A majority of these learners came from the Tamil monolingual community that was caught in between the globalisation era and the military rule. Further, their parents and siblings probably lost the socio-economic and educational opportunities of the country compared to the rest of the other non-war affected community. Added they faced bitter experiences, deprivations and difficulties during the civil war period of the country. There was awareness on English learning but there was no development of English teaching during the civil war period [Canagarajah, 2005]. Specifically, these learners did not meet the national requirements of the Sri Lankan education system. Within such a circumstance English hap- pens to be the only way for these learners to rise from the ashes by gaining the socioeconomic power of the country. This situation has created a strong ideal L2 self among the war affected science undergraduates. Thus for these war affected learners learning English is the only way up to gain the empowerment of the country. Further, they have realised the invalidity of the Tamil diaspora due to the loss of military power and naturally they were motivated to English learning due to the empowerment attached to it. Further, they have realised the possibility of challenging the disadvantageous social conditions with English education. Specifically, the caste based rigid social mobility among the Tamil community [Canagarajah, 2008] is a big challenge for them.

Further, these participants were schooling during the civil war period in northern and eastern areas of Sri Lanka. During this period they were subjected to the Tamil monolingual regional policy and restricted to the usage of "pure Tamil" [Canagarajah, 2005]. Thus these learners had limited opportunity to learn English. On the other hand, the military war caused the displacement of civilians, disruption of education, unspecified number of deaths and injuries, including children, teachers and their family members. As a result of the war, up to 300,000 people were held in refugee camps [Save the Children, 2013]. Thus, civil war has done unlimited psychological and physical damages for these learners. Furthermore, after the end of civil war in 2009 these learners had to face the challenges of global and local requirements of English. In one way English happened to be the key for "nationism" of Sri Lanka to create the harmony between the inter-ethnic communities [Lim, 2013, Rajandran, 2009] and in the other way English is the economic and symbolic capital of the country [Canagarajah, 2005].

In addition, English could be a weapon for the war affected Tamils to defend themselves against the majority language [Annamalai, 2004] of Sinhala. English proficiency would be able to provide them the opportunity to gain the economic capital and empowerment of the country. Thus for them Sinhala is an invader and English is a "protector" or "virus protection system" [Schiffman, 2005] to survive in the Sri Lankan linguistic, economic, political and social context.

Further, war affected learners have motivation to learn English, because the universities located in the other parts of the country conducted all science degree courses in English, they have to sit for the competitive examinations in English, and they have to communicate with the majority of the country by using English. In fact, English happens to be the compulsory medium to proceed their activities in the country.

These factors critically influence the formation of a strong ideal L2 self or speaking self of the war affected science undergraduates. Specifically, the effects of the civil war and their minority condition in Sri Lanka motivate them to learn English. In addition, war affected 


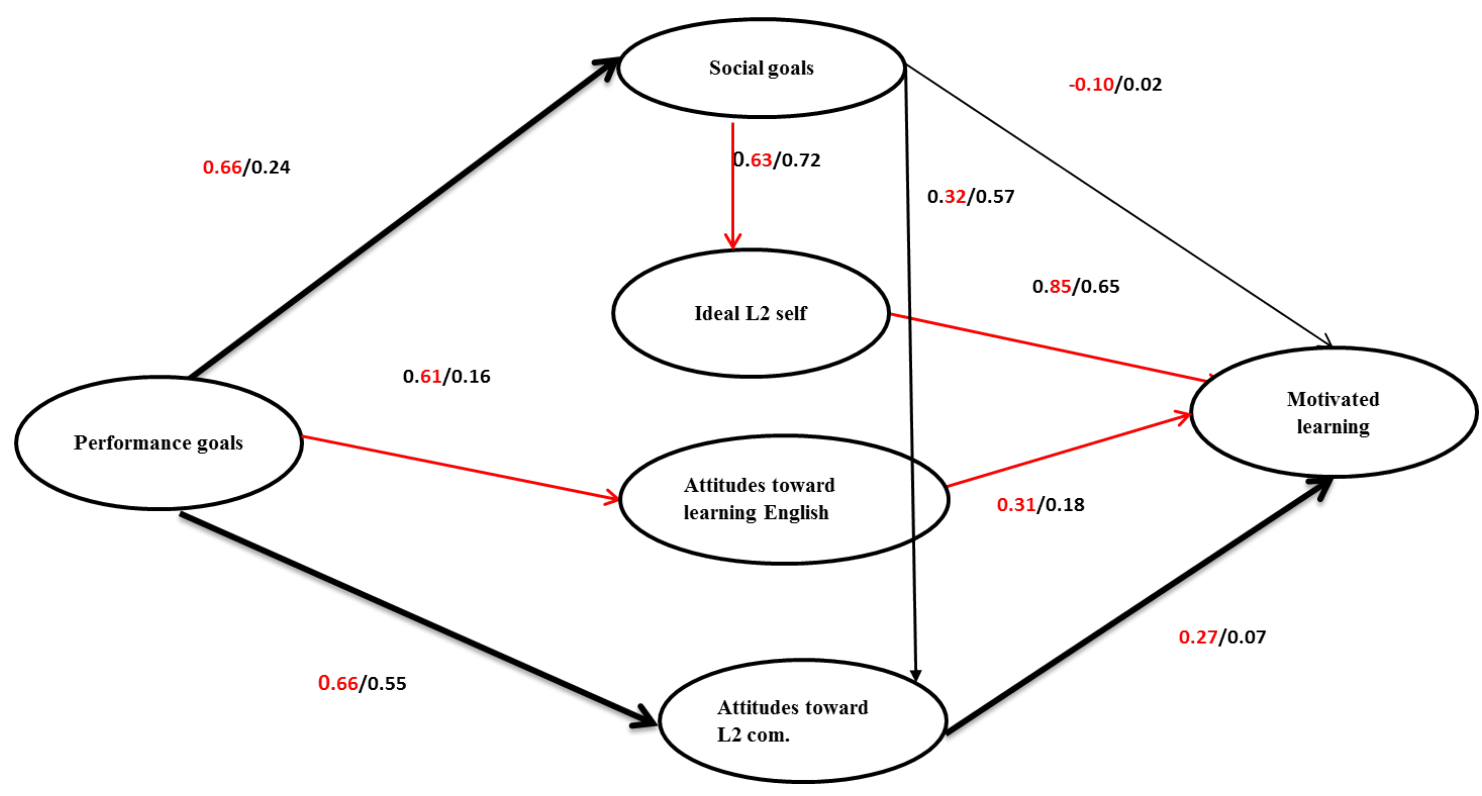

Figure 3: Rural Tamil and rural Sinhala undergraduates motivated learning behaviour

and rural Tamil science undergraduates' attitudes toward learning English is also higher than the non-war affected learners. This might be because these learners have to depend on the classroom learning experiences due to the lack of their parents' support. Further, the Tamil monolingual policy during the civil war period totally restricted the wider exposure to the English language. Thus they value classroom learning more than the non-war affected learners. This has demonstrated in the descriptive analysis via the favourable attitudes toward classroom learning experiences.

Furthermore, war affected and rural Tamil science undergraduates' attitudes toward L2 community have a contribution to their English learning motivation. This shows their favourable attitudes toward the English speaking countries like Australia, Canada, United Kingdom and etc. where they can seek the educational and professional opportunities. They see these countries as their future success in education and profession. In fact, they see these countries and people as global leaders. They may believe that migration is a solution to gain the economic and social capital they lack in the country and English as a "source of empowerment" [Canagarajah, 2008] for them. This context motivates the war affected learners to learn English more than the non-war affected learners.

In addition, war affected and rural Tamil learners' performance goals are higher than non-war affected learners. This is because these learners have to compete with the non-war affected majority of the country in every aspect of life. Since they understood English as their "protector" they try to be fluent more to survive in the country by defeating the socioeconomic and political barriers.

The findings related to the war affected learners can- not be denied in the education policy and language policy planning of Sri Lanka. This local knowledge reflects the true feelings and needs of these learners who suffered socially, economically and politically from the British colonisation onwards. Thus knowledge partnering and community partnership are essential for social innovation of Sri Lanka to heal the damages of the history and work together as a plural society. Further, at this stage it is worthwhile to pay special attention to the applicability of the existing university English courses to meet the needs of war affected science undergraduates because short term (30 hours) university course seemed to be inadequate for these learners.

\section{Conclusion}

This study used L2 Motivational Self System to investigate the factors affect for the L2 science undergraduates' English learning motivation based on their regional and communal differences. The Ideal L2 self is established as the strongest causative factor for learning English amongst rural and war affected Sri Lankan science undergraduates. Social goals remained as an equally strong factor. Besides that, performance goals, social goals, attitudes towards learning English, attitudes towards the L2 community appeared as the contributing factors for undergraduates generally. In sum this study highlighted the stronger ideal L2 self among the Sri Lankan undergraduates from disadvantageous regions including rural and war affected (resettled).

\section{References}

Altbach, P. G. (2005). Globalisation and the university: Myths and realities in an unequal world. Tertiary Education and Management, v.10(1), 
pp.3-25.

DOI:https://doi.org/10.1080/13583883.2004. 9967114

Annamalai, E. (2004). Nativization of English in India and its effect on multilingualism. JLP Journal of Language and Politics, v.3(1), pp.151-162. DOI:https://doi.org/10.1075/jlp.3.1.10ann

Bailey, R. W. (1998). Majority language, minority misery: The case of Sri Lanka. In D. A. Kibbee (Ed.), Language legislation and linguistic rights. Amesterdam: John Benjamins Publishing Company.

DOI:https://doi.org/10.1075/impact.2.14bai

Baldsing, L. (2013). Making English as a lynchpin for globalisation of education in Sri Lanka: Quality versus equality. Edith Cowan University.

Bernaisch, T. (2012). Attitudes towards Englishes in Sri Lanka. World Englishes, v.31(3), pp.279-291. DOI:https://doi.org/10.1111/j.1467-971x.2012. 01753.x

Canagarajah, A. S. (2005). Dilemmas in planning English/vernacular relations in post-colonial communities. Journal of Sociolinguistics, v.9(3), pp.418-447.

DOI:https://doi.org/10.1111/j.1360-6441.2005. 00299.x

Canagarajah, A. S. (2008). Language shift and the family: Questions from the Sri Lankan Tamil diaspora. Journal of Sociolinguistics, v.12(2), pp.143-176.

DOI:https://doi.org/10.1111/j.1467-9841.2008. 00361.x

Canagarajah, A. S. (2009). Reconstructing local knowledge, reconfiguring language studies. In A. S. Canagarajah (Ed.), Reclaiming the local in language policy and practice, London: Taylor and Francis. DOI:https://doi.org/10.1207/S15327701JLIE0104_1

Csizér, K., \& Kormos, J. (2009). Learning experiences, selves and motivated learning behaviour: A comparative analysis of structural models for Hungarian secondary and university learners of English. In Z. Dornyei \& E. Ushioda (Eds.), Motivation, language identity and the L2 self. Bristol: Multilingual Matters.

DOI:http://dx.doi.org/10.21832/9781847691293006

Davis, C. P. (2015). Speaking conflict: Ideological barriers to bilingual policy implementation in civil war Sri Lanka. Anthropology \& Education Quarterly, v.46(2), pp.95-112.

DOI:http://dx.doi.org/10.1111/aeq.12093

Department of Census and Statistics. (2001). Brief analysis of population and housing characteristics and housing censuses in Sri Lanka. Colombo: Department of Statistics.

Dörnyei, Z. (2009). The L2 Motivational Self System. In Z. Dörnyei \& E. Ushioda (Eds.), Motivation, Language Identity and the L2 self. Bristol,UK: Multilingual Matters.

DOI:https://doi.org/10.21832/9781847691293-003

Dörnyei, Z., \& Ushioda, E. (2011). Teaching and researching motivation. Harlow: Pearson. DOI:https://doi.org/10.1111/j.1540-4781.2012. 01340.x

Elabbar, A. (2016). Libyan Political Conflict : Effects on Higher Education Development, Scientific Research Journal v. 4(12), pp.1-16.

Eversole, R. (2015). Knowledge partnering for community development. Oxon: Routledge. DOI:http://dx.doi.org/10.4324/9781315774985

Fernando, C. (1977). English and Sinhala bilingualism in Sri Lanka. Language in Society, v.6(3), pp.341-360. DOI:https://doi.org/10.1017/ s004740450000505

Gardner, R. C. (1985). The Social Psychology and Second Language learning Role of Attitudes and Motivation. London: Edward Arnold.

DOI:https://doi.org/10.1017/S0272263100007634

Hair JR, J. F., Black, William, C., Babin, B. J., \& Anderson, R. E. (2014). Multivariate Data Analysis (7th ed.). London: Pearson.

Hayes, D. (2010). "Education is all about opportunities, isn't it?": A biographical perspective on learning and teaching English in Sri Lanka. Harvard Educational Review, v.80(4), pp.517-541.

DOI:https://doi.org/10.17763/haer.80.4. w732427072788342

Islam, M., Lamb, M., \& Chambers, G. (2013). The L2 Motivational Self System and National Interest: A Pakistani perspective. System, v.41(2), pp.231244. DOI:https://doi.org/10.1016/j.system.2013.01.025

Kandiah, T. (1984). "Kaduva": Power and the English language weapon in Sri Lanka. In P.C. Thome \& A. Halpe (Eds.), Honouring EFC Ludowyk. Dehiwala: Tisara Prakashakayo.

Kormos, J., \& Kiddle, T. (2013). The role of socioeconomic factors in motivation to learn English as a foreign language: The case of Chile. System, v.41(2), pp.399-412.

DOI:https://doi.org/10.1016/j.system.2013.03.006

Kormos, J., Kiddle, T., \& Csizér, K. (2011).Systems of goals, attitudes, and self-related beliefs in secondlanguage-learning motivation: An interactive model of language learning motivation. Applied Linguistics, 
v.32(5), pp.495-516.

DOI:https://doi.org/10.1093/applin/amr019

Lamb, M. (2012). A Self System Perspective on Young Adolescents ' Motivation to Learn English in Urban and Rural Settings. Language Learning, v.62(4), pp.9971023.

DOI:https://doi.org/10.1111/j.1467-9922.2012. 00719.x

Lim, L. (2013). Kaduva of privileged power, instrument of rural empowerment? The politics of English (Sinhala and Tamil) in Sri Lanka. In L. Wee \& B. H. Goh, Robbie (Eds.), The politics of English: South Asia, South East Asia and the Aisa Pacific. Amesterdam: John Benjamins Publishing Company.

DOI:https://doi.org/10.1075/wlp.4.06lim

Liyanage, I. K. (2014). Education system of Sri Lanka: Strengths and weaknesses. Institute of Developing Economies, Japan External Trade Organization, pp.116-140.

Ministry of Education Sri Lanka. (2013). Sri Lanka education information 2012. Colombo: Ministry of Education.

Papi, M. (2010). The L2 Motivational Self System, L2 anxiety, and motivated behavior: A Structural Equation Modeling approach. System, v.38(3), pp.467479.

DOI:https://doi.org/10.1016/j.system.2010.06.011

Prasangani, K. S. N., \& Nadarajan, S. (2015). Sri Lankan Urban and Rural Undergraduates' Motivation to Learn English. International Journal of Technical Research and Applications, v.18(June), pp.2633.

Punchi, L. (2001). Resistance Towards the Language of Globalisation The Case of Sri Lanka. International Review of Education. v.3(4), pp.47- 361. DOI:https://doi.org/10.1023/A:1017962029317

Raheem, R., Medawattegedera, V., \& Miththapala, G. (2007). International language assessment and local performance: The case of the Postgraduate Institute of Medicine. OUSL Journal, v.4, pp.3-16.

DOI:http://dx.doi.org/10.4038/ouslj.v4i0.335

Raheem, R., \& Wijetunge, L. D. L. (2009). Investigating undergraduate English language proficiency in the Sri Lankan university system. Paper presented at the Annual Academic Sessions of the Open University of Sri Lanka, The Open University of Sri Lanka, Nawala.

Rajandran, K. (2009). Then and now: English in Sri Lanka's public sector. Journal of Human Sciences, v.6(1), pp.1-13.

Ratwatte, H. (2012). Kaduwa, Karavila or Giraya? Orientation towards English in $21^{\text {st }}$ century Sri Lanka. Journal of Humanities \& Scocial Sciences, v.7(8), pp.180-203.

Save the Children. (2013). Education in emergencies in Sri Lanka (20012010). Colombo: EML Consultants.

Schiffman, H. F. (2005). Bilingualism in South Asia: Friend or foe?. In Proceedings of the 4th International Symposium on Bilingualism, Temple: Arisona State University. Retrived December 2013 from http://www.ccat.sas.upenn.edu/ $\sim$ haroldfs/public/finalisimo.pdf

Senaratne, C. D. (2009). Sinhala-English code-mixing in Sri Lanka: A sociolinguistic study. Utrecht: Radboud University.

Taguchi, T., Magid, M., \& Papi, M. (2009). The L2 motivational self system among Japanese, Chinese and Iranian learners of English: A comparative study. In Z. Drnyei \& E. Ushioda (Eds.), Motivation, language identity and the L2 self. Bristol: Multilingual Matters.

DOI:https://doi.org/10.21832/9781847691293-005

Tardy, C. (2004). The role of English in scientific communication: lingua franca or Tyrannosaurus rex?. Journal of English for academic purposes, v.3(3), pp.247-269.

DOI:https://doi.org/10.1016/j.jeap.2003.10.001

UNICEF. (2013). Country studies: Out of school children in Sri Lanka. Colombo: UNICEF.

DOI:http://dx.doi.org/10.15220/uis-unicef-cntrysri-lanka-2013-en

You, C. J., \& Drnyei, Z. (2016). Language learning motivation in China: Results of a large-scale stratified survey. Applied Linguistics, v.37(4), pp.495-516. DOI:https://doi.org/10.1093/applin/amu046

Wedikkarage, L. K. (2009). Science education and English medium: The Sri Lankan experience. In B. Birgit \& G. Gunnar (Eds.), Language and power: The implications of language for peace and development. Dares Salaam: Nyota.

Weerasekara, I., Wadugodapitiya, S., Liyanage, E., Dissanayaka, T., Liyanage, I., Kodikara, D., \& Banneheka, S. (2014). Influence of English on academic performance of physiotherapy students. International Journal of Multidisciplinary and Development, v.1(7), pp.169-172. 


\section{Appendix - Motivational Questionnaire}

\section{Motivated Learning}

1. If an English course was offered for my course at the university, I would like to take it.

2. If an on-line English course was offered for my course at a western (US/UK/Australia) university or in western institute (British council, US embassy, Australian High Commission and etc.) during my course, I would like to take it.

3. I am prepared to spend a lot of effort in learning English for my major subjects.

4. I think that I am doing my best to improve English at the university.

5. I would like to improve my English via social media.

6. I enjoy learning English from reading magazines and newspapers.

7. I enjoy learning English from listening to English songs.

8. I enjoy learning English from watching English movies.

9. If I have access to English-speaking TV stations (Dialog/Peo TV ) and movies, I would try to watch them often.

10. I really want to improve my English at the university.

\section{Ideal L2 Self}

11. I can imagine myself studying in a Sri Lankan university where all my courses are taught in English and spoken in English.

12. I can imagine myself writing e-mails/letters fluently in English.

13. The things I want to do in the future involve English.

14. I often imagine myself as someone who's able to speak good English.

15. I want to be the kind of Sri Lankan who speaks English fluently.

16. I see myself one day communicating in English with western speakers.

17. Studying English is important to me because I would like to become close to L1( US/British/Australian \& etc) speakers of English.

18. Studying English is important to me because I would like to become close to L2 (Sri Lankan/Malaysians/Indians \& etc.) speakers of English.

\section{Ought to L2 Self}

19. I have to study English, because, if I do not study it, I think my parents will be disappointed with me.

20. My parents believe that I must study English to be an educated person.

21. It will have a negative impact on my academic, professional and social life if I don't learn English.

22. University students are required to learn English well.

\section{Social Goals}

23. Studying English is important to me in order to attain a higher social respect in Sri Lanka.

24. Studying English can be important to me because I think it will someday be useful to have a good job and/or to earn money in Sri Lanka.

25. Studying English can be important to me because someday it will be useful in business communication in most of the English speaking countries.

26. I have to study English; otherwise, I think I cannot be successful in my profession.

27. Studying English is important to me because I don't want to be seen as a less educated person in Sri Lanka.

28. Knowledge of English would help Sri Lankans to represent country in a better way before other nations globally.

29. Knowledge of English language is necessary for Sri Lankans to benefit from the scientific development in the world.

30. Competency of English language is necessary for me to contribute to the national development of Sri Lanka in a better way with the international community.

\section{Mastery Goals}

31. Studying English is important to me to be a wellinformed person in Sri Lanka.

32. Studying English is important to me so that I can broaden my outlook about the world.

33. Studying English is important to me so that I can read English books, newspapers, or magazines in my working place.

34. Studying English is important to me because an educated person is supposed to be able to speak good English.

\section{Performance Goals}

35. I have to learn English because it is compulsory to obtain my degree.

36. I have to study English in the university because I don't want to get bad marks in it at university.

37. Studying English is important for me because I think I'll need it for further studies on my major.

38. Studying English is necessary for me because I don't want to get a poor score or a fail mark in English proficiency tests (IELTS/TOEFL).

\section{Attitudes Towards Learning English}

39. I like the atmosphere of my university English classes.

40. My English course should be in the first year.

41. My English course should be in the second year.

42. My English course should be in the third year.

43. I find learning English is really interesting at the university.

44. My university English teachers make lessons really interesting. 